\title{
Effect of 1-MCP, Ethylene Absorber and Ozone on Melon Quality during Storage
}

\author{
Lien PHUONG Le NGUYeN ${ }^{1,2^{*}}$, VIVIEN HORVÁTH ${ }^{1}$, MAI SAO DAM ${ }^{2}$, \\ GÉZA HITKA ${ }^{1}$, TAMÁs ZSOM${ }^{1}$, ZOLTÁN KÓKAI ${ }^{1}$
}

\begin{abstract}
This work was aimed to investigate the effect of 1-methylcyclopropene (1$\mathrm{MCP}$ ), ethylene absorber (EA), ozone alone or in combination on melon quality during storage. Ethylene production, respiration rates, acoustic firmness, surface color, chilling injury, and disease severity of melon were determined. 1-MCP treated fruits and non 1$\mathrm{MCP}$ treated fruits were stored with sachets of ethylene absorber containing $\mathrm{KMnO}_{4}$ or ozone at $0.1 \mathrm{ppm} / \mathrm{h}$ during 10 days at $5{ }^{\circ} \mathrm{C}$ and subsequent 4 days at $20{ }^{\circ} \mathrm{C}$. Melons treated with 1-MCP were firmer than the rest of the samples during storage. In addition, 1-MCP reduced the yellowing of melon rind compared to other treatments. The combination of 1-MCP and EA did not offer any additional effect in comparison with 1MCP alone. There was no significant difference between fruits stored with ethylene absorber, ozone and control samples. Ozone treatment during cold storage decreased disease severity, however, fruits exposed to ozone had more serious decay throughout storage at $20^{\circ} \mathrm{C}$, probably due to the unclean air in the chamber.
\end{abstract}

Keywords: 1-MCP, ethylene absorber, ozone, melon, storage

\section{Introduction}

Cantaloupe is a delicious fruit with a juicy texture and high nutritional value, however, this fruit is perishable. In order to extend postharvest life of melon, the two main problems such as rapid postharvest ripening and microbial quality should be considered together (Aharoni et al., 1993; Ukuku, 2006).

* Corresponding author. E-mail: Nguyen.Le.Phuong.Lien@etk.szie.hu

1Szent István University, Faculty of Food Science, Department of Postharvest Science and Sensory Evaluation, Budapest, Hungary

2Biotechnology and Food Technology Institute, Industrial University of Ho Chi Minh City, Ho Chi Minh, Vietnam 
The aim of this study was to evaluate the effect of 1-MCP, ethylene absorber (EA), ozone alone or in combination on melon during 10 days of cold storage at $5{ }^{\circ} \mathrm{C}$ and subsequent 4 days at $20^{\circ} \mathrm{C}$.

\section{Materials and Methods}

\section{Materials}

Samples of melons (Cucumis melo. var. reticulates L Naud. 'Donatello') were harvested while at $1 / 2-3 / 4$ slip stage from an experienced grower in July 2016, Hungary.

1-MCP $\left(0.14 \%\right.$ 1-MCP tablet, SmartFresh ${ }^{\circledR}$, AgroFresh, Philadelphia, USA) as an application of SmartFresh ${ }^{\circledR}$ system was provided by Rohm and Haas Polska Sp.z.o.o.

Sachets of ethylene absorber (Ethyl Stopper, Bioconservacion S.A., Spain) containing $\mathrm{KMnO}_{4}$ were used to remove the ethylene in the chamber.

Gaseous ozone at an average concentration of $0.1 \mathrm{ppm} / \mathrm{h}$ was generated by an ozone generator (Neo. Tec XJ-100, China).

\section{Methods}

\section{Experimental design}

Fruits were selected for uniformity of size, and absence from external damage. 'Donatello' melons were divided randomly into 6 groups. Each group contained 15 fruits. Melons were cooled down to $5{ }^{\circ} \mathrm{C}$ before treatment. Three groups were treated with gaseous 1-MCP in an air-tight plastic box at $5{ }^{\circ} \mathrm{C}$ on the $1^{\text {st }}$ day after harvest for $24 \mathrm{~h}$. During the $24 \mathrm{~h}$ long treatment, three control groups (non 1-MCP treated groups) were stored separately at 3 different storage conditions:

Storage condition 1: cold storage at $5{ }^{\circ} \mathrm{C}+$ ozone $0.1 \mathrm{ppm} / \mathrm{h}$.

Storage condition 2: cold storage at $5{ }^{\circ} \mathrm{C}+6$ sachets of ethylene absorber.

Storage condition 3: only cold storage at $5{ }^{\circ} \mathrm{C}$. 
Table 1. Storage conditions

\begin{tabular}{|c|c|c|}
\hline \multirow{2}{*}{ Storage condition } & Samples \\
\hline \multirow{4}{*}{$\begin{array}{c}\text { Cold storage at } 5{ }^{\circ} \mathrm{C} \\
\text { for } 10 \text { days }\end{array}$} & Ozone $0.1 \mathrm{ppm} / \mathrm{h}$ & 1-MCP treated group \\
\cline { 2 - 3 } & Ethylene absorber (EA) & 1-MCP treated group \\
\cline { 2 - 3 } & Only cold storage at $5{ }^{\circ} \mathrm{C}$ & Control \\
\cline { 2 - 3 } & at $20^{\circ} \mathrm{C}$ & Control \\
\hline $\begin{array}{c}\text { Ambient temperature } \\
\text { storage for } 4 \text { days }\end{array}$ & & 6 groups \\
\hline
\end{tabular}

After 1-MCP application, three 1-MCP treated groups were put into 3 different storage conditions above (Table 1). All six groups were stored for 10 days at $5^{\circ} \mathrm{C}$, and then transferred to $20^{\circ} \mathrm{C}$ for 4 days.

\section{Measurements}

The disease severity and chilling injury were assessed initially before storage (day 0 ), and on the $4^{\text {th }}, 8^{\text {th }}, 10^{\text {th }}$, and $14^{\text {th }}$ day.

The ethylene and $\mathrm{CO}_{2}$ production, acoustic firmness, and surface color were measured before storage (day 0 ) and on the $10^{\text {th }}$ and $14^{\text {th }}$ day.

Acoustic firmness (Stiffness, $\mathrm{Hz}^{2} \cdot \mathrm{g}^{2 / 3}$ ) of samples was determined at two opposite sides on the exterior circumference of each fruit, using an AWETA table top acoustic firmness sensor model DTF V0.0.0.105 (AWETA, Nootdorp, The Netherlands).

Ethylene production was determined by a portable ethylene meter (ICA-56, International Controlled Atmosphere Ltd., UK) upon the measured ethylene production of the samples being held for a given time (about an hour) in a hermetically closed plastic container. Ethylene production were expressed per fresh weight $\left(\mu \mathrm{l} \mathrm{kg}^{-1} \mathrm{~h}^{-1}\right)$.

Respiratory intensity as carbon dioxide production was measured for an hour in a closed respiratory system equipped with FY A600-CO2H carbon dioxide sensors connected to an Almemo 3290-8 data logger (Ahlborn Mess- und Regelungstechnik GmbH, Germany). Carbon dioxide production were expressed per fresh weight $\left(\mathrm{ml}^{\mathrm{kg}} \mathrm{kg}^{-1} \mathrm{~h}^{-1}\right)$.

Melon rind color was measured with a portable chroma meter (CR-400, Minolta Corporation, Osaka, Japan). CIE $\mathrm{L}^{*}, \mathrm{a}^{*}$ and $\mathrm{b}^{*}$ color characteristics 
were determined at three equidistant points on the equatorial circumference of each fruit. Hue angle $\left(\mathrm{H}^{\circ}\right)$ value was calculated as arctangent $(b / a)$.

Chilling injury (CI) symptom was determined as brownish pitting and water-soaked areas on melon rind surface and evaluated on a scale of 1-5, where: (1) no CI; (2) CI area $\leq 10 \%$; (3) CI area from 11 to $25 \%$; (4) CI area from 26 to $50 \%$; (5) CI area $\geq 50 \%$ (Yang et al., 2003).

Disease severity of melons was tested for mould growth on melon rind or stem during storage period, and assessed on a scale of 1-3, where 1 means good, fruit without decay (without mould on the rind or stem), 2 means fair, fruit with moderate decay; 3 means bad, fruit with severe decay. Disease severity was calculated as the average score of all melons within a group (Yang et al., 2003).

\section{Statistical analysis}

All data were processed by SPSS (SPSS Inc, USA) using analysis of variance (ANOVA) with the following factors: treatment type (1-MCP, non 1-MCP); storage condition (ozone, ethylene absorber) and storage period $(0,10$, and 14 days), followed by Tukey's method with a significance level of $p<0.05$. The results were reported with mean and standard deviation.

\section{Results and Discussion}

\section{Ethylene and $\mathrm{CO}_{2}$ production}

As shown in Fig. 1a, the ethylene production of fruits treated with 1-MCP was significantly lower than others. Untreated samples had high ethylene production persisting during the whole storage. EA or ozone alone did not show any benefit in declining ethylene production compared to control (Fig. $1 a)$. In addition, the combination of 1-MCP and EA or ozone did not have any additional advantages in comparison with 1-MCP. Similarly, 1-MCP application also influenced $\mathrm{CO}_{2}$ production more strongly than other treatments (Fig. 1b). No difference was detected in respiration rates between control, and fruits treated with EA or ozone. 

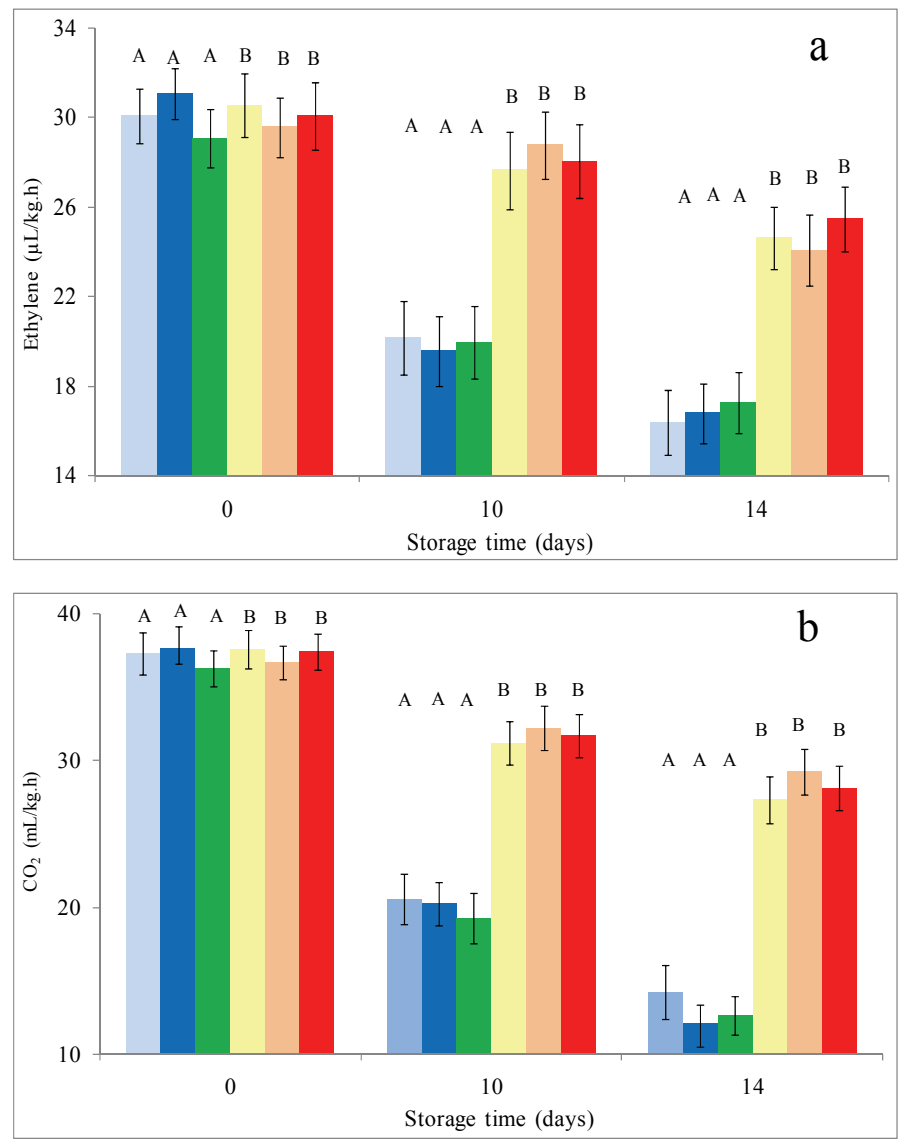

Fig. 1. Ethylene (a) and $\mathrm{CO}_{2}$ (b) production of melon during 10 days of storage at $5{ }^{\circ} \mathrm{C}$ and 4 days of shelf-life at $20^{\circ} \mathrm{C}$. Values are the mean \pm SD $(\square 1-\mathrm{MCP}$ and Ozone; 1-MCP and EA; 1-MCP; EA; Ozone; $\square$ Control). Different letters show significant differences based on treatments (Tukey's test, $p<0.05$ )

\section{Acoustic firmness and hue angle value}

The acoustic firmness and hue angle values of all melons declined with increasing storage period, but at different rates (Fig. 2). The decrease of acoustic firmness indicated that the mechanical texture of samples changed and the softening took place throughout storage. This was in agreement with earlier reports (Zsom-Muha \& Felföldi, 2007; Zsom et al., 2016). According to these differences, there were two distinct groups: 1-MCP treated samples retained firmness more than control, EA or ozone treated 
fruits (Fig. 2a). Application of 1-MCP dramatically inhibited ethylene action inducing the ripening of melon. Consequently, fruits exposed to 1-MCP treatment had higher firmness and hue angle values compared to others during the experiment (Fig. 2). In contrast, the presence of EA or ozone did not affect significantly firmness and hue angle values vs. control throughout storage $5{ }^{\circ} \mathrm{C}$ and $20^{\circ} \mathrm{C}$. Also, the chlorophyll fluorescence parameters did not show any difference between control and EA or ozone treated fruits (data not shown). Fruits previously stored in EA or ozone further continued normal ripening during storage at $20{ }^{\circ} \mathrm{C}$, similarly to control. On the contrary, 1-MCP further delayed the ripening during storage at $20^{\circ} \mathrm{C}$.

1-MCP markedly delayed the ripening of melon, could maintain melon quality during 10 days at cold storage and 4 days of shelf-life compared to other treatments. This was corresponding with previously reported results (Ergun et al., 2005; Gal et al., 2006; Shi et al., 2014). Ethylene absorber and 1MCP have been used widely to control ethylene action, in order to delay ripening during transportation and storage, however, each of them has its different impact. In case of 1-MCP treatment, ethylene receptor was blocked, while ethylene removal decreased ethylene level in the storage environment, particularly in sealed environment such as controlled atmosphere and packaging (Terry et al., 2007; Watkins, 2006). It is assumed that $1-\mathrm{MCP}$ binds irreversibly to the ethylene receptors (Meyer and Terry, 2010). Therefore, 1-MCP could maintain the effect during the whole storage, while the ethylene absorber could not have an effect on the samples when fruits were removed from the chamber. Fruits resume normal ripening when removed from ethylene absorber (Meyer and Terry, 2010; Silva et al., 2009). In this work, melon treated with 1-MCP did not fully ripen, in accordance with an earlier report for avocado (Meyer and Terry, 2010). The combination of 1-MCP and ethylene absorber did not have any additional effect in comparison to 1-MCP alone.

The results showed that ozone treatment had no effect in maintaining melon quality compared to control samples. A number of studies reported that ozone treatment proved effective in extending shelf-life of persimmon (Salvador et al., 2006), papaya (Ali et al., 2014), broccoli and cucumber (Skog and $\mathrm{Chu}, 2001)$. However, there was no effect of ozone treatment on apple and pear (Skog and Chu, 2001). Thus, ozone efficacy might depend on produce (Liew and Prange, 1994). In this work, samples treated with ozone or ethylene absorber alone had no significant effect during storage compared to control samples. 

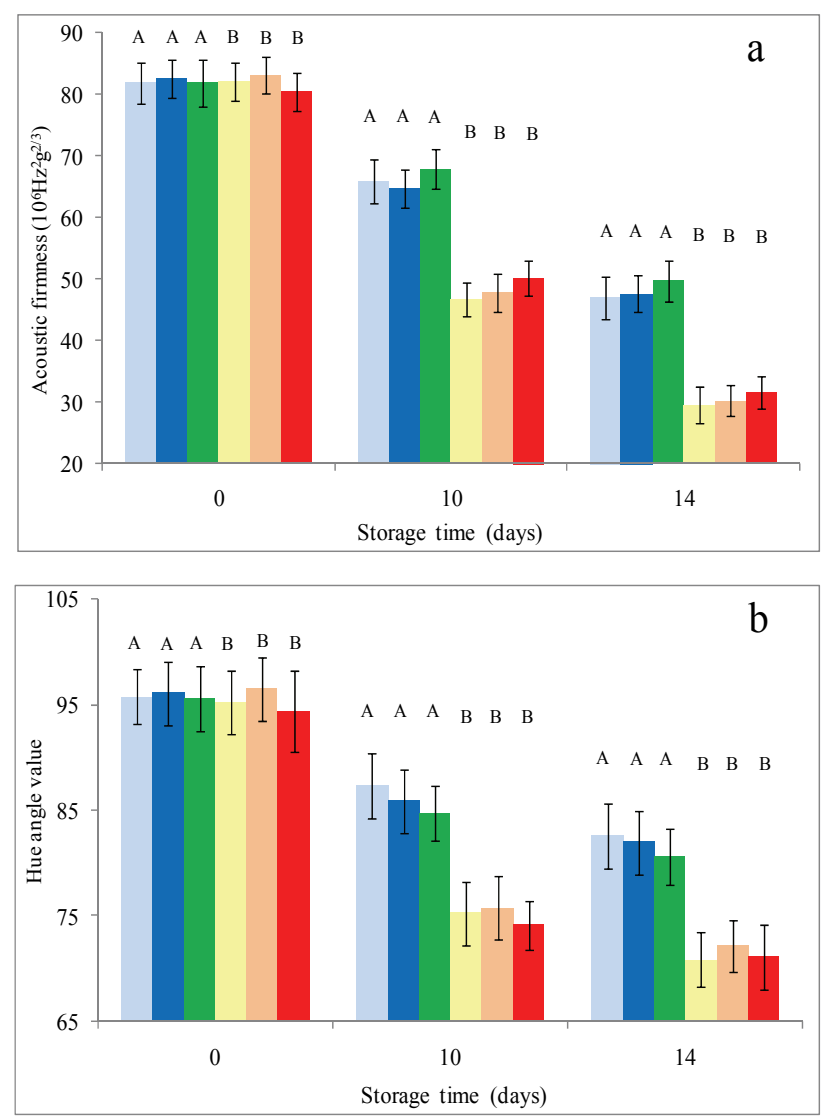

Fig. 2. Acoustic firmness (a) and hue angle value (b) of melon during 10 days of storage at $5{ }^{\circ} \mathrm{C}$ and 4 days of shelf-life at $20^{\circ} \mathrm{C}$. Values are the mean \pm SD $(\square 1-\mathrm{MCP}$ and Ozone; -1-MCP and EA; 1-MCP; EA; Ozone; $\square$ Control). Different letters show significant differences based on treatments (Tukey's test, $\mathrm{p}<0.05$ )

\section{Chilling injury}

There was a minor difference in sensitivity to $\mathrm{CI}$ between treatments during storage (Table 2). Storing at $5{ }^{\circ} \mathrm{C}$ induced $\mathrm{CI}$ on melon skin. CI developed on approximately $10 \%$ of the melon surface area on the $4^{\text {th }}$ day of cold storage and increased scores were found with extending cold storage duration. Samples stored with ozone were more sensitive to CI than other samples, however, the significant difference was only observed on $10^{\text {th }}$ day of storage. 
Table 2. Chilling injury rating of melon during storage. Means followed by the same letters are not significantly different at the same measurement time (Tukey's, $\mathrm{p}<0.05$ )

\begin{tabular}{|c|c|c|c|c|c|}
\hline Treatments & 0 & 4 & 8 & 10 & 14 \\
\hline 1-MCP & & & & & \\
\hline 1-MCP + EA & 1.0 & $1.8 \mathrm{a}$ & $2.1 \mathrm{a}$ & $2.1 \mathrm{a}$ & $2.1 \mathrm{a}$ \\
\hline 1-MCP + ozone & 1.0 & $1.9 \mathrm{a}$ & $2.1 \mathrm{a}$ & $2.1 \mathrm{a}$ & $2.1 \mathrm{a}$ \\
\hline EA & 1.0 & $1.9 \mathrm{a}$ & $2.4 \mathrm{a}$ & $2.5 \mathrm{~b}$ & $2.5 \mathrm{~b}$ \\
\hline Ozone & 1.0 & $2.1 \mathrm{a}$ & $2.4 \mathrm{a}$ & $2.1 \mathrm{a}$ & $2.1 \mathrm{a}$ \\
\hline Control & 1.0 & $1.9 \mathrm{a}$ & $2.1 \mathrm{a}$ & $2.1 \mathrm{a}$ & $2.1 \mathrm{a}$ \\
\hline
\end{tabular}

Ozone treatment had higher CI rates perhaps due to cuticle damage caused by the oxidizing activity of ozone (Aliet al., 2014; Salvador et al., 2006). Therefore, skin was more susceptible to low temperature.

\section{Disease severity}

The early sign of microbial decay occurred on the $8^{\text {th }}$ day of storage and developed rapidly during shelf-life (Table 3). Low temperature could slow the microbial growth. Ozone was effective in inhibiting microbial development throughout cold storage, however, fruits previously stored with ozone had serious decay during shelf-life. 1-MCP treated samples had less decay than others except the combination of 1-MCP and ozone. There was no significant difference in decay between fruits treated with EA, ozone or control.

Table 3. Disease severity of melon during storage. Means followed by the same letters are not significantly different at the same measurement time (Tukey's, $\mathrm{p}<0.05$ )

\begin{tabular}{|c|c|c|c|c|c|c|}
\hline Treatments & 0 & 4 & 8 & 10 & 12 & 14 \\
\hline 1-MCP & 1.0 & 1.0 & $1.1 \mathrm{a}$ & $1.1 \mathrm{a}$ & $1.3 \mathrm{a}$ & $1.7 \mathrm{a}$ \\
\hline 1-MCP + EA & 1.0 & 1.0 & $1.1 \mathrm{a}$ & $1.1 \mathrm{a}$ & $1.4 \mathrm{a}$ & $1.9 \mathrm{a}$ \\
\hline 1-MCP + ozone & 1.0 & 1.0 & $1.0 \mathrm{a}$ & $1.0 \mathrm{a}$ & $1.7 \mathrm{ab}$ & $2.5 \mathrm{~b}$ \\
\hline EA & 1.0 & 1.0 & $1.1 \mathrm{a}$ & $1.3 \mathrm{ab}$ & $1.5 \mathrm{ab}$ & $2.5 \mathrm{~b}$ \\
\hline Ozone & 1.0 & 1.0 & $1.0 \mathrm{a}$ & $1.0 \mathrm{a}$ & $1.7 \mathrm{ab}$ & $2.7 \mathrm{~b}$ \\
\hline Control & 1.0 & 1.0 & $1.3 \mathrm{a}$ & $1.5 \mathrm{~b}$ & $1.7 \mathrm{ab}$ & $2.5 \mathrm{~b}$ \\
\hline
\end{tabular}


Fruits stored with ozone showed less disease severity than those of other treatments during cold storage due to antimicrobial efficacy of ozone (Guzel-Seydim et al., 2004). The result of this work was corresponding with previous report (Palou et al., 2002). Nonetheless, melons exposed to ozone prior to shelf-life had more serious decay throughout ambient storage at $20{ }^{\circ} \mathrm{C}$ than the rest because a cleaner surface may be more vulnerable to recontamination (Gil et al., 2009; Ukuku, 2006).

\section{Conclusion}

This work confirmed a benefit of $1-\mathrm{MCP}$ in delaying the ripening of 'Donatello' melon. 1-MCP treatment could restrain the softening and slow the rind color change during the whole storage period. Ozone had an effect on inhibiting microbial development during storage, however, fungal growth was much more prominent when fruits were removed for further ambient temperature storage. Ethylene absorber did not show any advantages throughout storage period.

\section{References}

Aharoni, Y., Copel, A., \& Fallik, E.(1993). Storing Galia melons in a controlled atmosphere with ethylene absorbent. HortScience, 28(7), 725-726.

Ali, A., Ong, M. K., \& Forney, C. F. (2014). Effect of ozone pre-conditioning on quality and antioxidant capacity of papaya fruit during ambient storage. Food Chemistry, $142,19-26$.

Ergun, M., Jeong, J., Huber, D. J., \& Cantliffe, D. J. (2005). Suppression of ripening and softening of 'Galia' melons by 1-methylcyclopropene applied at preripe or ripe stages of development. HortScience, 40(1), 170-175.

Gal, S., Alkalai-Tuvia, S., Elkind, Y., \& Fallik, E. (2006). Influence of different concentrations of 1-methylcyclopropene and times of exposure on the quality of 'Galia' type melon harvested at different stages of maturity. Journal of Horticultural Science and Biotechnology, 81(6), 975-982.

Gil, M. I., Selma, M. V., López-Gálvez, F., \& Allende, A. (2009). Fresh-cut product sanitation and wash water disinfection: problems and solutions. International Journal of Food Microbiology, 134(1), 37-45.

Guzel-Seydim, Z. B., Greene, A. K., \& Seydim, A. C. (2004). Use of ozone in the food industry. LWT - Food Science and Technology, 37(4), 453-460.

Liew, C. L., \& Prange, R. K. (1994). Effect of ozone and storage temperature on postharvest diseases and physiology of carrots (Daucus carota L.). Journal of the American Society for Horticultural Science, 119(3), 563-567. 
Meyer, M. D., \& Terry, L. A. (2010). Fatty acid and sugar composition of avocado, cv. Hass, in response to treatment with an ethylene scavenger or 1methylcyclopropene to extend storage life. Food Chemistry, 121(4), 1203-1210.

Palou, L. S., Crisosto, C. H., Smilanick, J. L., Adaskaveg, J. E., \& Zoffoli, J. P. (2002). Effects of continuous $0.3 \mathrm{ppm}$ ozone exposure on decay development and physiological responses of peaches and table grapes in cold storage. Postharvest Biology and Technology, 24(1), 39-48.

Salvador, A., Abad, I., Arnal, L., \& Martínez-Jávega, J. M. (2006). Effect of ozone on postharvest quality of persimmon. Journal of Food Science, 71(6), 443-446.

Shi, Y., Wang, B., Shui, D., Cao, L., Wang, C., Yang, T., \& Ye, H. (2014). Effect of 1methylcyclopropene on shelf life, visual quality and nutritional quality of netted melon. Food SciTechnol Int.

Silva, D. F. P., Salomão, L. C. C., Siqueira, D. L. D., Cecon, P. R., \& Rocha, A. (2009). Potassium permanganate effects in postharvest conservation of the papaya cultivar Sunrise Golden. Pesquisa Agropecuaria Brasileira, 44(7), 669-675.

Skog, L. J., \& Chu, C. L. (2001). Effect of ozone on qualities of fruits and vegetables in cold storage. Canadian Journal of Plant Science, 81(4), 773-778.

Terry, L. A., Ilkenhans, T., Poulston, S., Rowsell, L., \& Smith, A. W. (2007). Development of new palladium-promoted ethylene scavenger. Postharvest Biology and Technology, $45(2), 214-220$.

Ukuku, D. O. (2006). Effect of sanitizing treatments on removal of bacteria from cantaloupe surface, and recontamination with Salmonella. Food Microbiology, 23(3), 289-293.

Watkins, C. B. (2006). The use of 1-methylcyclopropene (1-MCP) on fruits and vegetables. Biotechnology Advances, 24(4), 389-409.

Yang, B., Shiping, T., Hongxia, L., Jie, Z., Jiankang, C., Yongcai, L., \& Weiyi, Z. (2003). Effect of temperature on chilling injury, decay and quality of Hami melon during storage. Postharvest Biology and Technology, 29(2), 229-232.

Zsom-Muha, V., \& Felfödi, J. (2007). Vibration behavior of long shape vegetables. Progress in Agricultural Engineering Sciences, 3(1), 21-46.

Zsom, T., Zsom-Muha, V., Dénes, D., Baranyai, L., \& Felföldi, J. (2016). Quality changes of pear during shelf-life. Progress in Agricultural Engineering Sciences, 12(1), 81-106.

Zsom-Muha, V., \& Felfödi, J. (2007). Vibration behavior of long shape vegetables. Progress in Agricultural Engineering Sciences, 3(1), 21-46. 